\title{
The Relationships Between Job Embeddedness, Person-Organization Fit, and Turnover Intention
}

\author{
Albertha Haga Ciptaningtyas, P. Tommy Y. S. Suyasa, and Linda Wati \\ Faculty of Psychology \\ Universitas Tarumanagara
}

\begin{abstract}
This study aim to examine the relationships between job embeddedness, person-organization fit (POF), and turnover intention. Job embeddedness is a variety of conditions that make individuals feel attached to their job and organization. Person-organization fit is the compatibility between the characteristics of individuals and their organizations. Turnover intention is an employee's conscious desire to leave his or her organization. This study was conducted among employees of a retail company in West Jakarta. The number of participants in this study was 177 employees. Data analysis was performed using Spearman correlation. Results show that job embeddedness was related to person-organization fit and turnover intention. However, there was no relationship between turnover intention and person-organization fit.
\end{abstract}

Keywords: job embeddedness, person-organization fit, turnover intention

Studi ini bertujuan melihat hubungan antara job embeddedness, person-organization fit (POF), dan turnover intention. Job embeddedness merupakan berbagai kondisi yang membuat individu merasa lekat dengan pekerjaan dan juga dengan organisasinya. Person-organization fit adalah kesesuaian antara karakteristik individu dan karakteristik organisasi. Turnover intention merupakan keinginan secara sadar yang dimiliki karyawan untuk meninggalkan organisasi. Studi ini dilakukan pada karyawan perusahaan retail di Jakarta Barat. Jumlah partisipan dalam penelitian ini adalah 177 karyawan. Analisis data dilakukan dengan metode Spearman correlation. Hasil penelitian menunjukkan bahwa job embeddedness berhubungan dengan person organization fit dan turnover intention. Tidak ada hubungan antara turnover intention dan person organization fit.

Kata kunci: job embeddedness, person-organization fit, turnover intention

In line with today's globalization, a company should prepare for changes and challenges in order to survive. For this reason, the employees of a company are required to be productive to maintain the company's reputation. A company often tries to enhance the employees' performances by encouraging them to produce a maximum output. In reality, employees encounter problems in their work, indicating a discrepancy between employers' expectations and employees' needs or desires. This has caused employees to quit their jobs, a situation which is known as turnover.

It is common that every company has problems with employee turnover. This problem could disrupt its business operation. For instance, due to a vacant

Correspondence concerning this letter should be addressed to Albertha Haga Ciptaningtyas, Faculty of Psychology Universitas Tarumanagara. E-mail: albertha.705130045@stu.untar.ac.id position in a company, the workload of employees who remain in the company is increased. Those who stay with the company have to take over the work from those who quit the job. Turnover can actually be identified from the beginning. Before a person decides to quit his/her job, he/she experiences withdrawal processes (withdrawal cognitions), involving thoughts about leaving the company which is called turnover intention (Mobley cited in Holtom, Mitchell, Lee, \& Eberly, 2008).

Since a desire to quit a job provides negative consequences for a company, more specifically it disrupts its business operation, it is important to prevent turnover earlier by identifying turnover intention. Based on recent research (Holtom, Lindsay, Smith, \& Burton, 2014), job embeddedness and person-organization fit predicted turnover intention. Employees might not feel attached to their company because they have uncomfortable relationships with their co- 
workers. For this reason, they tend to choose another company that provides them with the opportunity to establish comfortable relationship with co-workers (Mitchell, Holtom, Lee, Sablynski, \& Erez, 2001). Job embeddedness focuses on the attachment that links individuals to their work and organization. This has become the main reason that makes employees stay in their job. The more employees have job embeddedness, the less likely they have a desire to leave the company.

In addition to job embeddedness, person-organization fit could also predict turnover intention. Person-organization fit is defined as the compatibility between employees' characteristics and organizational values. Apart from values, person-organization fit includes the compatibility between employees' and organization's goals. If there are many incompatibilities between employees' characteristics and organizational values and goals, then employees are more likely to have turnover intention (Jin, McDonald, \& Park, 2016). Numerous studies (O'Reilly, Chatman, \& Caldwell, 1991; Kristof, 1996; Kristof-Brown, Zimmerman, \& Johnson, 2005) indicate that personorganization fit is associated with turnover.

Holtom et al.'s study (2014) showed that personorganization fit and job embeddedness were the variables with the highest coefficient correlation with turnover intention, particularly when compared to other variables, such as job satisfaction and organizational commitment. Thus, the levels of turnover intention could be predicted by person-organization fit (i.e., the compatibility between the characteristics or skills of employees and organizational values and job demands) and job embeddedness (i.e., attachment or comfortable relationships with co-workers).

Holtom et al. (2014) have proposed that personorganization fit and job embeddedness predicted turnover intention. However, it should be noted that the participants in Holtom et al.'s study were air force cadets. We argue that the result of a study with cadets might not be generalizable to employees of PT X. This might be due to differences in characteristics between cadets and employees. Overall, the present study that investigated person-organization fit, job embeddedness, and turnover intention among employees of PT X could have different results with past research that studied the same variables.

Differences in characteristics between cadets and employees can be explained as follows. Since air force cadets have a high esprit de corps (Baja, 2016), their job embeddedness are also relatively high.
Meanwhile, employees of PT X do not have a high esprit de corps; therefore, their job embeddedness might not as high as air force cadets. The levels of job embeddedness between air force cadets and employees may vary, potentially causing different correlation coefficients of job embeddedness and turnover intention between the two samples.

Differences in characteristics between cadets and employees may also lead to differences in personorganization fit. Attitudes and behaviors of cadets are based on military values. Military values are largely derived from the history of experiences possessed by the members of a military force. The history of experiences of the members of a military force have been adopted and used as a tradition that influence day-to-day attitudes and behaviors of cadets (Supriyatno, 2014). Thus, attitudes and behaviors of cadets might be different from those of employees based on their shared values. The values held by employees might not be as strong as the values held by the members of a military force.

Furthermore, cadets and employees of PT X have different status. Cadets are students aiming to finish their study or complete their education, notably they have received some support for meeting their basic needs (residential cost and food expenses). In contrast, employees of PT X have the status as a worker aiming to meet day-to-day needs. Differences in values and status between cadets and employees might lead to differences in person-organization fit. Due to differences in person-organization fit between the two samples, the results of a study by Holtom et al. (2014) could not be generalized to employees of PT X.

Thus, in this present study, we would investigate if turnover intention could be explained by job embeddedness and person-organization fit among employees of PT X.

\section{Turnover Intention}

A definition of turnover intention according to Cohen (1999) is an employee's thoughts about the possibility to stay with a company or to move to another work place. Martin and Hafer (1995) assume that if the status of an employee is not full-time, he/ she is more likely to have turnover intention, using his or her spare time to work for another company. Jung and Yoon (2013) indicate that turn-over intention is a condition in which individuals have the feeling to quit their current job or have a consideration to stay in their job until they retire. 


\section{Job Embeddedness}

Job embeddedness refers to a broad constellation or condition that influences employee retention (Mitchell, Holtom, Lee, Sablynski, \& Erez, 2001). The concept of job embeddedness departs from two theories. The first one is Kurt Lewin's field theory (cited in Mitchell et al., 2001). The theory is about the ideas that individuals have which are manifested in the perceived life spaces that are connected and attached to each other. The second theory is embedded figures theories (Mitchell et al., 2001), the concept is taken from the images used in a psychological test with the same name. According to Mitchell et al., embedded figures represent individuals' attachment to their environment where they are connected with the entire background. In other words, they are difficult to be separated from their surroundings because they have been parts of the environment.

There are three important aspects in job embeddedness according to Mitchell et al. (2001). The first aspect focuses on the degree to which individuals have relationships with other people or activities. Second, it focuses on the degree to which their work and community are compatible with the aspects of their lives. Finally, it relates to the ease in building relationships. Long-standing relationships are usually vulnerable if individuals have to leave, particularly when they physically move, for example, to another city or house. The three aspects are summarized into dimensions of job embeddedness, which are links, fit, and sacrifice.

March, Simon, and Hulin (cited in Lee, Mitchell, Sablynski, Burton, \& Holtom, 2004) conclude that job embeddedness can be divided into two components: on-the-job embeddedness and off-the-job embeddedness. On-the-job embeddedness relates to links, fit, and sacrifice within an organization. Meanwhile, offthe-job embeddedness is associated with links, fit, and sacrifice within the scope of community. Thus, the total number of dimensions in job embeddedness that are associated with the two aforementioned components are six.

It can be concluded that job embeddedness is employees' attachment to their work. The attachment occurs because of individuals' compatibility with their organization, community and work environment. The impact of job embeddedness is that it can increase trust relationships with supervisors or superiors (Purba, Oostrom, Born, \& van der Molen, 2016). Particularly, in Indonesia, employees' trust in supervisors is important for social identification. If the in-group relationships in the workplace are good, then they will lead to supportive feelings and behaviors for the company. The higher the job embeddedness, the lower the employees' desire to move.

The dimension of links is characterized by both formal and informal relationships between individuals and institutions or other people. The links in the context of embeddedness are described as employee-family relationships (in social, psychological, and financial contexts). This includes colleagues and non-colleagues, groups, communities, and physical environments in which they live. The higher the links between a person and his or her contexts, the more likely that the person feel attached to his/her work and organization (Mitchell et al., 2001).

The dimension of fit refers to the suitability or comfort perceived by employees to their organization or environment. Theoretically, it is aligned with personal values, career goals, and plans that employees have for the future. It is also in line with corporate culture and job demands. Additionally, employees consider to what extent they feel compatible with their surroundings and community. The more they feel compatible or suitable with their surroundings, the more likely that they perform professionally and personally attached to their organization (Mitchell et al., 2001).

Finally, sacrifice is described as a person's sacrifice that includes the loss of benefits in terms of material or psychological costs or burdens. The loss is felt because a person leaves his or her job. For example, as a consequence of leaving his or her organization, a person does not receive allowances and have the projects that he or she used to have (Mitchell et al., 2001). Notably, job embeddedness results in the possibility to predict job performances and organizational citizenship, particularly in the context of on-the-job embeddedness (Lee, Mitchell, Sablynski, Burton, \& Holtom as cited in Lee, Burch, \& Mitchell, 2014). Another consequence is that job embeddedness could influence the spread of ideas and innovations, particularly among employees with high level positions (Ng \& Feldman, cited in Lee et al., 2014).

\section{Person-Organization Fit}

The concept of person-organization fit was developed from Schneider's (1987) attraction-selection-attrition (ASA) model and the social exchange theory (Blau, as cited in Jin et al., 2016). ASA contain perspectives, which can build high person-organization fit in an organization. Attraction, is an initial 
process experienced by an individual in finding attraction between self-characteristics towards organization's values. Selection is a formal or informal procedure in an organization during recruitment and placing employees according to the needs of the organization. Attrition is a final stage where the misfitting employees would be more likely to make errors once hired and therefore choose or are forced to leave the organization. The people remaining are a more homogeneous group than those who were originally hired (Kristof-Brown \& Guay, 2011).

The second theory is the social exchange theory, employees feel compatible with their organization because they have to fulfill their obligations to the organization. This might result in employees stay longer with the organization (Jin et al., 2016). Kristof (1996) defines POF as the compatibility between individuals or employees and the organization. The most important point is the compatibility of employees' personality with the overall organizational culture, rather than with the characteristics of a particular job.

In the context of person-organization fit, it is assumed that people who work for an organization are those who are interested with and selected by the organization. They are selected because they are compatible with the organizational values. Those who plan to leave the organization are individuals whose personality is not compatible with the organization's culture. This concept is related to the Big Five theory (Robbins \& Judge, 2014). For example, a person with a high level of extraversion personality would be compatible with an aggressive and team-oriented culture. A person with a high level of agreeableness personality would be compatible with a supportive organizational climate rather than an aggressive organizational culture. Finally, a person with a high level of openness personality, based on his or her experiences working at the organization, tends to emphasize innovation rather than standardization (Robbins \& Judge).

POF can be explained in two different concepts. The first concept as proposed by Muchinsky and Monahan (cited in Kristof, 1996) consists of two dimensions of supplementary fit and complementary fit. Supplementary fit indicates that the compatibility between individuals and an organization occurs if the characteristics of individuals are similar to those of organization. Complementary fit indicates that the compatibility between individuals and an organization occurs when there is a complementarity between the two. Both the individuals and their orga- nization are complement to each other.

The second concept consists of needs-supplies and demands-abilities (Kristof, 1996). Need-supplies show that the compatibility occurs when an organization meets individuals' needs, desires, and preferences. Demands-abilities show that the compatibility occurs when individuals have the capabilities to meet the needs or demands of the organization. To conclude, the compatibility between individuals and their organization occurs when: (a) one party meets the needs of the other; (b) both parties have the same characteristics; (c) both points occur.

It can be concluded that person-organization fit occurs if there is compatibility between individuals and the company where they work. This includes the compatibility between employees' personal values and their company's values, as well as between organizational demands and employees' needs. The impact of POF is related to organizational commitment (Noe, Hollenbeck, Gerhart, \& Wright, 2011; Khaola \& Sebotsa, 2015).

\section{Job Embeddedness and Turnover Intention}

Employee turnover is preceded by a thought or an intention to leave the company, which is known as turnover intention (Mobley cited in Holtom et al., 2008). Turnover intention is employees' desire to consciously leave the organization (Tett \& Meyer, 1993). Based on studies conducted by Felps et al. (2009), Purba, Oostrom, Born, and van der Molen (2016), turnover intention can be predicted by one of the factors of job embeddedness.

Job embeddedness (JE), a construct developed by Mitchell et al. (2001), is related to employees' evaluation towards their co-workers, specifically the degree of relationships between employees and their co-workers, the degree of compatibility between employees and their company, and the degree to which employees feel the loss if they leave the company. The relationship between JE and turnover intention can be explained by the social learning theory. Felps et al. (2009) used the theory to explain the relationship between JE and turnover intention. Since employees develop an attachment to their co-workers, they influence each other in displaying certain behavior, in this case the behavior or intention to work for another company. A co-worker who has previously no intention to work for another company might be influenced and now have the intention to do so. An example of behavior is looking for information about job vacancies or vacant position via the Internet. 
A relationship attachment can increase the trust between superior and subordinate (Purba et al., 2016). Purba et al. shows that the feeling of trust to superiors is positively and significantly related to on-thejob relationships. Particularly in Indonesia, employees' trust in their superior is important for social identification. It can foster in-group relationships in the workplace leading to feelings and behaviors that are supportive to the company. The higher the work attachment, the lower the desire of employees to find another workplace. If employees have low job embeddedness, then their intention to leave the company tends to be high (Holtom et al., 2008).

It was hypothesized that there was a relationship between job embeddedness and turnover intention.

\section{Person-Organization Fit and Turnover Intention}

In the context of person-organization fit, it is assumed that people who work for the organization are those who are interested with and selected by the organization. They are selected because they are compatible with organizational values. Those who plan to leave the organization are individuals whose personality is not compatible with organization culture. This concept is related to the Big Five theory (Robbins \& Judge, 2014). For example, a person with a high level of extraversion personality would be compatible with an aggressive and team-oriented culture. A person with a high level of agreeableness personality would be compatible with a supportive organizational climate rather than an aggressive organizational culture. Finally, a person with a high level of openness personality, based on his or her experiences working at the organization, tends to emphasize innovation rather than standardization (Robbins \& Judge).

Next, research by Peng, Lee, and Tseng (2014) showed that work engagement was the mediator variable that decreased employee turnover intention and improved person-organization fit $(\beta=.453, p<$ $.001)$. In the study, the hospital management supported nurses' psychological development through work engagement. For example, the hospital improved the compatibility between employee and organizational value systems through recruitment and organizational socialization. The compatibility between employee and organizational values would certainly strengthen nurses' work involvement and reduce their turnover intention. In addition, there is a person-context interface factor that might cause an individual to have intention to leave the company. Thus, one factor that is related to turnover intention is personfit. If individuals have values and goals that are not compatible with the values and goals of the company, then they are considered having low levels of person-organization fit.

The second hypothesis was formulated as follows: there is a relationship between person-organization fit and turnover intention.

\section{Methods}

\section{Participants and Procedures}

Participants in this study were 250 employees who work in a retail company. The number of participants with the age ranges of 17-25 years, 26-34 years, and $>35$ years were 122, 37, and 18 people, respectively. Participants in this study consist of 94 females and 83 males. There were 166 participants who completed senior high school or vocational school, 8 participants who completed first degree, and three participants with diploma qualifications. All employees in the store regardless of their position were involved in this study as participants. Their positions were supervisors, shop attendants, cashiers, customer services and so on.

This study started with a literature review of research variables. Then, we searched for suitable measures. After obtaining the measures for job embeddedness, person-organization fit, and turn-over intention, we adapted the measures. We then made a cover letter to ask permission to distribute questionnaires to employees at PT X stores.

\section{Measures}

Turnover Intention. The measure of turnover intention used in this study consists of seven items. The items were adapted and combined from several turnover intention measures (two items taken from Cohen, 1999; one item taken from Martin \& Hafer, 1995; and four items taken from Jung \& Yoon, 2013). Sample items include: "I feel like leaving my current job," "Shortly, I am going to leave the company where I currently work," and "Sometimes, I feel like leaving the job that I currently have." Responses were captured on five-point rating scales ranging from strongly disagree $(\mathrm{STS}=1)$, disagree $(\mathrm{TS}=2)$, agree $(\mathrm{S}=3)$, to strongly agree $(\mathrm{SS}=4)$. The higher the scores, the more likely that participants feel like quit- 
ting their current job and think that they will leave their workplace shortly. The seven-item turnover-intention measure was unidimensional and had an internal reliability coefficient of .802 .

Job Embeddedness. To measure job embeddedness, 26 items were used, comprising 19 items in a multiple choice format and seven items in a short answer format. The job embeddedness measure used in this study was adapted from the measure developed by Mitchell et al. (cited in Holtom et al., 2014). Conceptually, job embeddedness captures two areas, namely off-the-job embeddedness (attachment to community) and on-the-job embededdness (attachment to work environment/organization). In this study, we focused on on-the-job embededdness. According to Purba (2015), this area has good construct validity (convergent evidence) with the measure of trust in supervisor, and it can better explain work outcomes. In other words, it has criterion validity with the measure of turnover intention. This area includes three dimensions: links, fit, and sacrifice.

The dimension of links was measured using seven items with a short answer format. The example of item is "How long have you worked in this company?" The internal consistency of the links dimension was .60. The fit dimension was measured using nine items, such as "I feel compatible with working atmosphere in this company". The internal consistency of the fit dimension was .76. The sacrifice dimension was measured using 10 items, such as "I receive enough benefits". The internal reliability coefficient was .80. Since the dimension of links was in a short answer format (scoring 0,1 , or 2 ) or have a different scale with the sacrifice and fit dimensions (scoring from 1 to 4 ), the three dimension scores were transformed into standardized scores $(z$-scores) with mean $=0$.

Person-Organization Fit (POF). To assess POF, this study used the measure developed by Holtom et al. (2014). Based on Holtom et al.'s study, the measure has good construct validity (convergent evidence) with the measures of job satisfaction, affective commitment, and normative commitment. The measure consists of 12 items (11 positive and one negative statements). An example of a positive statement is "I feel compatible with the rule of conducts, manners, and attitude in this company," whereas an example of a negative statement is "I do not think that my knowledge, skills, and abilities meet the criteria set by my company." The internal consistency for person-organization fit measure was .82 . The higher the POF scores, the more compatible the values held by individuals with the needs of company. Responses were captured on four-point rating scales ranging from strongly disagree (STS $=1$ ), disagree (TS $=2)$, agree $(S=3)$, to strongly agree $(S S=4)$.

\section{Results}

Prior to data analysis, we conducted normality tests. The results showed that data of turnover intention, job embeddedness, and person-organization fit were not normally distributed. Therefore, we used Spearman-Brown correlation for the analysis.

Testing first hypothesis. Using Spearman correlation at the alpha level of .05 , it was found that there was a significant relationship between job embeddedness $(M d=-0.077)$ and turnover intention $(M d=2.43), r_{s}(177)=-.223, p<.01$. This indicates that the lower the attachment to the company (because employees do not feel compatible with his or her co-workers), the higher their intention to leave the company. Thus, the first hypothesis was confirmed (see Table 1).

Testing second hypothesis. Based on the result of Spearman correlation at the alpha level of .05, the relationship between POF $(M d=3.00)$ and turnover intention $(M d=2.43)$ was not significant, $r_{s}$ $(177)=-.119, p>.05$. This indicates that although employees feel compatible with the values and goals of the company, their intention to leave the company is not necessarily low. Thus, the second hypothesis was not confirmed.

\section{Discussion}

Although this study was conducted with employees as participants, the results are similar to the previous

Table 1

Descriptive Statistics and Correlations Between

Job Embeddedness, Person-Organization Fit and Turnover Intention

\begin{tabular}{|c|c|c|c|c|}
\hline No. & Variable & $\begin{array}{c}M d \\
\text { (Median) }\end{array}$ & 1 & 2 \\
\hline 1 & $\begin{array}{l}\text { Turnover } \\
\text { Intention }\end{array}$ & 2.43 & & \\
\hline 2 & $\begin{array}{l}\text { JE- } \\
\text { Organization }\end{array}$ & -0.077 & $-.223^{* * *}$ & \\
\hline 3 & POF & 3.00 & -.119 & $.630^{* * *}$ \\
\hline
\end{tabular}


research that was conducted with air force cadets. The results only partly support the results from the previous study by Holtom et al. (2014) indicating that POF was negatively associated with turnover intention. Despite this, job embeddedness-organization was found having a negative relationship with turnover intention. This is similar to the finding in the previous study by Holtom et al. The coefficient correlation of job embeddedness-organization and turnover intention in employees seems slightly higher than that in air force cadets. This might mean that the contribution of JE to turnover intention in employees is slightly higher than that in cadets. In employees, the intention to leave the company is more strongly predicted by JE. However, in cadets, POF seems to play a more role than JE in predicting turnover intention. This is interesting because both JE and POF are the factors that predict turnover intention, but their roles might be different in different organizations.

Based on the results of this study, it can be concluded that employee turnover intention (excluding those who work in military organizations) is predicted more strongly by employees' attachment to their co-workers, suitability or compatibility with their work, and feeling of not wanting to lose the benefits commonly received. Meanwhile, turnover intention of cadets is explained more strongly by the compatibility between cadets and their military organizations in terms of values and goals. Based on the concept of POF (Kristof, 1996), the compatibility occurs when individuals have the abilities to meet organizational demands. Thus, turnover intention in cadets seems to be more strongly predicted by the abilities to obtain organizational goals and demands rather than by attachment to peers or benefits received.

Obtaining goals seems to be more important than attachment to co-workers or environment. In other words, cadets seem to be more concerned with the compatibility of their abilities or values and the values and goals of their military organization; it is not important whether they are comfortable or uncomfortable with their co-workers and organizational environment (superiors), and whether they receive or does not receive benefits.

\section{Limitations and Further Studies}

There are at least two limitations in this study. First, participants in this study are limited to employees of PT. X. To verify different contributions of POF and JE to turnover intention in employees and in cadets, it is necessary to involve participants who have the same characteristics as cadets. Therefore, further research should examine different contributions of POF and JE among employees and cadets. Second, the result showed that POF had a positive relationship with JE. This indicates that the higher the suitability or compatibility between employees and their organization in goals and values, the greater the employees' attachment to their environment or work and their dislike to lose the benefits received. However, in this study, it is still not clear whether JE mediates the relationship between POF and turnover intention. Further research could examine the possibility that JE is the mediator between POF and turnover intention.

The subsequent development of the concept of turnover intention includes the concept of proximal withdrawal states (PWS). This concept needs to be further considered because turnover intention is not always related to turnover behavior. For example, one of the PWS conditions is reluctant stayers. According to Li, Lee, Mitchell, Hom, and Griffeth (2016), reluctant stayers is a condition in which employees have a desire to leave the company but there is something that makes them remain in the company. This condition occurs because they feel "embedded" with the existing culture in the company, but not with their work.

\section{Conclusion}

This study points out many factors influencing turnover intention. The alignment of an individual's characteristics with the characteristics of an organization (person-organisation fit) doesn't always guarantee an employee will confine his/her desire to change jobs (turnover intention). One matter which will cause a person to hold fast and not change jobs is job embeddedness. Desire, involvement, and commitment to the field of employment in which he/she is engaged would more make a person familiar with his/ her position and reduce his/her turn-over intention.

\section{References}

Baja. (Agustus, 2016). Rahasia terbentuknya jiwa korsa TNI. Retrieved from: http://www.kodam17 cenderawasih.mil.id/rahasia-terbentuknya-jiwakorsa-tni/

Cohen, A. (1999). Turnover intention scale [Database record]. Retrieved from PsycTESTS. https://doi. 
org/10.1037/t10116-000

Felps, W., Mitchell, R. T., Hekman, D. R., Lee, T. W., Holtom, B. C., \& Harman, W. S. (2009). Turnover contagion: How coworkers' job embeddedness and job search behaviors influence quitting. Academy of Management Journal, 52(3), 545561. https://doi.org/10.5465/AMJ.2009.41331075

Holtom, B. C., Mitchell, T. R., Lee, T. W., \& Eberly, M. B. (2008). Turnover and retention research. The Academy of Management Annals, 2, 231-274. https://doi.org/10.1080/19416520802211552

Holtom, B. C., Lindsay, D. R., Smith, D. R., \& Burton., J. P. (2014). Relative strength of job attitudes and job embeddedness in predicting turnover in a U.S. Military Academy. Military Psychology, 26, 397-408. https://doi.org/10.1037/mil00 00055

Jin, M.H., McDonald, B., \& Park, J. (2016). Personorganization fit and turnover intention: Exploring the mediating role of employee followship and job satisfaction through conservation of resources theory. Review of Public Personnel Administration, 1-26. https://doi.org/10.1177/0734371X16658334 [Google Scholar]

Jung, H. S., \& Yoon, H. H. (2013). Role stress and turnover intent measure [Database record]. Retrieved from PsycTESTS. https://doi.org/10.1037/ t24169-000

Khaola, P. P., \& Sebotsa, T. (2015). Person-organisation fit, organisational commitment and organisational citizenship behaviour. Danish Journal of Management and Business Sciences, July, 6774. https://doi.org/10.6084/m9.figshare. 1487700

Kristof, A. L. (1996). Person-organization fit: An integrative review of its conceptualizations, measurement and implications. Personnel Psychology, 49, 1-49. https://doi.org/10.1111/j.1744-6570.19 96.tb01790.x

Kristof-Brown, A. L., \& Guay, R. P. (2011). Personenvironment fit. In S. Zedeck (Ed.), American Psychological Association Handbook of industrial and organizational psychology (pp. 3-50). Washington, DC: American Psychological Association.

Kristof-Brown, A. L., Zimmerman, R. D., \& Johnson, E. C. (2005). Consequences of individuals' fit at work: A meta-analysis of person-job, person-organization, person-group, and person-supervisor fit. Personnel Psychology, 58, 281-342. https:// doi.org/10.1111/j.1744-6570.2005.00672.x

Lee, T. W., Mitchell, T. R., Sablynski, C. J., Burton, J. P., \& Holtom, B. C. (2004). The effects of job embeddedness on organizational citizenship, job performance, volitional absences, and voluntary turnover. The Academy of Management Journal, 47(5), 711-722. https://doi.org/10.2307/20159613

Lee, T. W., Burch, T.C., \& Mitchell, T. R. (2014). The story of why we stay: A review of job embeddedness. The Annual Review of Organizational Psychology and Organizational Behavior, 1, 199-216. https://doi.org/10.1146/annurev-orgpsych-031413091244

Li, J. J., Lee, T. W., Mitchell, T. R., Hom, P.W., \& Griffeth, R.W. (2016). The effect of proximal withdrawal states on job attitudes, job searching, intent to leave, and employee turnover. Journal of Applied Psychology, 101(10), 1436-1456. https:// doi.org/10.1037/apl0000147

Martin, T. N., \& Hafer, J. C. (1995). Intent to leave scale [Database record]. Retrieved from PsycTESTS. https://doi.org/10.1037/t13979-000

Mitchell, T. R., Holtom, B. C., Lee, T. W., Sablynski, C. J., \& Erez, M. (2001). Why people stay: Using job embeddedness to predict voluntary turnover. Academy of Management Journal, 44(6), 11021121.

Noe, R. A., Hollenbeck, J. R., Gerhart, B., \& Wright, P. M. (2011). Fundamentals of human resource management (4th ed.). New York, NY: McGraw-Hill.

O'Reilly, C. W., Chatman, J., \& Caldwell, D. F. (1991). People and organizational culture: A profile comparison approach to person-organization fit. Academy of Management Journal, 34, 487-516. https://doi.org/10.2307/256404

Peng, J. C., Lee, Y. L., \& Tseng, M. M. (2014). Person-organization fit and turnover intention: Exploring the mediating effect of work engagement and the moderating effect of demand-ability fit. The Journal of Nursing Research, 22(1), 1-11. https://doi.org/10.1097/jnr.0000000000000019

Purba, D. E. (2015). Employee embeddedness and turnover intentions: Exploring the moderating effects of commute time and family embeddedness. Makara Hubs-Asia, 19(1), 51-63. https://doi.org/ 10.7454/mssh.v19i1.xxxx

Purba, D. E., Oostrom, J. K., Born, M. P., \& van der Molen, H. T. (2016). The relationships between trust in supervisor, turnover intentions, and voluntary turnover: Testing the mediating effect aof on-the-job embeddedness. Journal of Personnel Psychology, 15(4), 174-183. https://doi.org/10. 1027/1866-5888/a000165

Robbins, S. P., \& Judge, T. A. (2014). Essentials of organizational behavior (12th ed.). New Jersey, USA: Pearson. 
Supriyatno, M. (2014). Tentang ilmu pertahanan. Jakarta: Pustaka Obor Indonesia.

Tett, R. P., \& Meyer, J. P. (1993). Job satisfaction, organizational commitment, turnover intention, and turnover Path analyses based on meta-analytic findings. Personnel Psychology, 46, 259-293. 